\title{
Longer religious fasting increases support for Islamist parties: Evidence from Ramadan
}

\author{
Ozan Aksoy ${ }^{1}$ \\ Department of Quantitative Social Science \\ University College London, UK
}

\author{
Diego Gambetta \\ Collegio Carlo Alberto \\ Turin, Italy
}

\begin{abstract}
:
Much scientific research shows that the sacrifices imposed by religious practices are positively associated with the success of religious organizations. We present the first evidence that this association is causal. We employ a natural experiment that rests on a peculiar timeshifting feature of Ramadan that makes the length of fasting time vary from year-to-year and by latitude. We find that an hour increase in fasting during the median Ramadan day increases the vote shares of Islamist political parties by about 6.5 percentage-points in Turkey's parliamentary elections between 1973 and 2018. This effect is weaker in provinces where the proportion of non-orthodox Muslims is higher, but stronger in provinces where the number of per capita mosques and of religious personnel is higher. Further analyses suggest that the main mechanism underlying our findings is an increased commitment to religion induced by costlier practice. By showing that the success of religious organizations is causally related to the sacrifice demanded by religious practices, these results strengthen a key finding of the science of religion.
\end{abstract}

Keywords: Science of religion; Ramadan; religious fasting; politics; voting; natural experiment

This Version: 09 March 2020 (First version: 09 October 2019)

Most religions require their adherents to engage in practices that involve the expenditure of significant amounts of resources in terms of time, energy, and material costs. Some of them can be also physically or psychologically taxing. Examples include onerous rituals, dietary and behavioral restrictions, charitable disbursements, and bodily alterations (e.g. circumcision or tattoos). A key conjecture in the science of religion is that such costly religious practices are crucial for the success of religious movements and organizations (Iannaccone 1992, Irons 2001, Sosis and Alcorta 2003, Sosis and Bulbulia 2011). These practices are thought to trigger two classes of mechanisms, screening and commitment (Aksoy and Gambetta 2016), both of which benefit religious organizations, movements, and communities.

\footnotetext{
${ }^{1}$ Corresponding author, ozan.aksoy@ucl.ac.uk, 55-59 Gordon Square WCH1 0NU, London United Kingdom. We thank Krzysztof Krakowski, Max Schaub, Richard Sosis, Werner Raub for their comments on earlier drafts, and the participants of the Collegio Carlo Alberto Politics and Society Seminar, Nuffield College Sociology Seminar, and UCL Quantitative Social Science Seminar for useful suggestions.
} 
As a screening mechanism, costly practices help religious organizations exclude from their ranks free riders and mimics - those who are not religious but may pass off to enjoy the benefits religious communities provide (think of Moliere's Tartuffe) (Iannaccone 1992, Irons 2001). Screening ensures that the remaining members are true believers. This increases the religious organizations' capacity to attain their goals and provide better services for their members (McBride 2007, Berman 2011).

Higher religious effort can also directly increase commitment to religious organizations and movements. Scholars have identified four mechanisms that could underlie this strengthening effect: $(i)$ restricting members' outside options and hence making them more dependent to the organization (Iannaccone 1992, 1994; Carvalho 2013), (ii) creating cognitive dissonance among the less religious who end up aligning their inner beliefs with their high effort (Festinger 1957, Sosis 2003), (iii) making individuals who are uncertain of their own level of beliefs infer those beliefs from their behavior (Bern 1965, Sosis 2003), and (iv) increasing religious group identity and cohesion through shared experiences of enduring hardship (Bastian, Jetten and Ferris 2014, Durkheim [1912] 1995, Power 2017).

Robust evidence of a positive effect of the cost of religious practice on the success of religious communities and organizations is, however, scarce. Studies show that religious sects and organizations that have more onerous rituals are also more successful in generating group cohesion (Iannaccone 1994, Sosis and Bulbulia 2011). Those studies, however, rely on observational data which cannot safely establish the presence of a causal effect. Experimental studies show that priming participants by reminding them of God and holding beliefs in moralistic and punitive gods increase altruism (Norezanyan and Shariff 2008, Lang et al. 2019, Purzycki et al. 2016, Purzycki et al. 2018), and that religious participants are more trustworthy compared with nonreligious participants (Tan and Vogel 2008, Hall et al. 2015). But those experiments do not manipulate directly of the cost of religious practices - it is of course close to impossible to do so in an experiment. Moreover, those laboratory experiments are typically restricted to individual level outcomes (e.g. altruism and trust) and do not include measures of organizational success.

In this study, we resort to a natural experiment that can reveal whether the cost of religious practice can be the cause of the success of religious movements. There is a peculiar feature of the timing of Ramadan that creates the conditions for a natural experiment, which has been exploited before by Campante and Yanagizawa-Drott 2015. Using this design, we study the effects of exogenous shifts in the cost of religious practice on a highly consequential indicator of the success of religious organizations, namely vote shares of Islamist political parties.

Ramadan is a holy month in Islam during which all Muslims are required to abstain from eating, drinking, smoking, and sexual activity between sunrise and sunset. These restrictions are broken after sunset (iftar) typically by sharing a meal with the family or the wider community. A special daily religious service (teravih) follows the fast break. The whole month of Ramadan is a highly spiritual period during which community service and charity activities intensify. Fasting is physiologically demanding. Practicing Muslims lose weight, some experience transient mental difficulties and headaches, and in utero exposure to fasting reduces birth weight; labor supply 
and activity are reduced (Almond and Mazumder 2011, Campante and Yanagizawa-Drott 2015, Oosterbeek and van der Klaauw 2013). Despite these difficulties, more than $80 \%$ of Muslims in Muslim majority countries adhere to the practice (PEW 2013).

The key feature of Ramadan for our study is that the starting day of Ramadan is determined by the lunar calendar, which is shorter than the solar calendar. This means that Ramadan shifts by about 11 days backwards in each year. When Ramadan falls in the summer months, the days are longer and hence fasting more demanding to bear. Moreover, the temporal change in the length of a Ramadan day varies by latitude: the more distant an area is from the equator, the higher is the temporal change in Ramadan day length. This interaction between the cyclical nature of the lunar calendar and the latitude is arguably exogenous to any variable of interest and provides a further independent variation in the cost of religious fasting (Campante and Yanagizawa-Drott 2015).

Using this design, Campante and Yanagizawa-Drott (2015) found that longer Ramadan days have a negative effect on economic growth, which they expected, but also a positive effect on subjective wellbeing, which they did not seem to expect. They explain the latter effect by invoking the screening mechanism discussed above. "[Costlier] practices" - they write - "may work as a mechanism for screening out individuals who are less committed to exerting effort within the community, as well as reducing the threat of free-riding, thereby increasing the intensity of participation of remaining members and the provision of the club good entailed by that religious engagement ( $\mathrm{p}$ 618)". Which in turn would increase subjective wellbeing. ${ }^{2}$

Neither economic growth nor subjective wellbeing are direct indicators of the success of religious organizations. To capture the latter, in this study we focus on vote shares for Islamist political parties and on the effect of longer fasting on these votes. The popular votes for Islamist parties are a good indicator of success of religious organizations for substantive and methodological reasons. Substantively, outside strict authoritarian regimes, religious organizations' power count in the world through elections. The electoral success of Islamic parties is directly correlated with the wider benefits Muslim religious communities receive (Aksoy and Billari 2018, Aksoy and Gambetta 2019). Moreover, where secret ballot is employed the party choice is, at least partially, voluntary. Methodologically, the advantage is that voting is a behavioral rather than attitudinal measure. Next, compared with other possible survey measures, in actual voting the measurement error and the social desirability bias should be both negligible. Last, there is high-quality and historical voting data available, which is not the case for most other measures of religious organizational success.

Our study is conducted using data from Turkey. Several properties of Turkey make it a suitable research site. Turkey is one of the most northern Muslim majority countries. This means that seasonal shifts in Ramadan day length varies considerably over time. Figure 1 below shows the most northern (Sinop) and southern (Hatay) provinces of Turkey and the length of Ramadan day

\footnotetext{
${ }^{2}$ Longer Ramadan days also seem to reduce terror incidents in Muslim majority districts and increase Muslim adolescents' educational attainment (Hornung, Schwerdt and Strazzeri 2018, Hodler, Raschky and Strittmatter 2019). The explanations of the authors for these findings are consistent with screening and commitment: costlier fasting increases engagement with the wider community and reduces anomie.
} 
in these two provinces since 1970s. This large variation is due to the northern latitude of the country. Next, Turkey has had a long string of political Islamic parties dating back to early 1970s which has built on a continual Islamist movement (Özbudun, 2006). The most recent of those parties is the AK Parti of Recep Tayyip Erdogan. With the exception of the 1983 elections marred by the 1980 military coup, in all parliamentary elections since 1973 there was at least one Islamist political party that participated. While Turkish democracy has been imperfect, elections, especially those before 2015 are considered to have been relatively free and fair (Akkoyunlu 2017).

FigURE 1. UPPER PANEL: TURKEY'S PROVINCES WITH THE MOST (SINOP) AND LEAST (HATAY) NORTHERN PROVINCES HIGHLIGHTED; LOWER PANEL: CHANGE IN THE RAMADAN DAY LENGTH IN SiNOP AND HATAY OVER TIME.
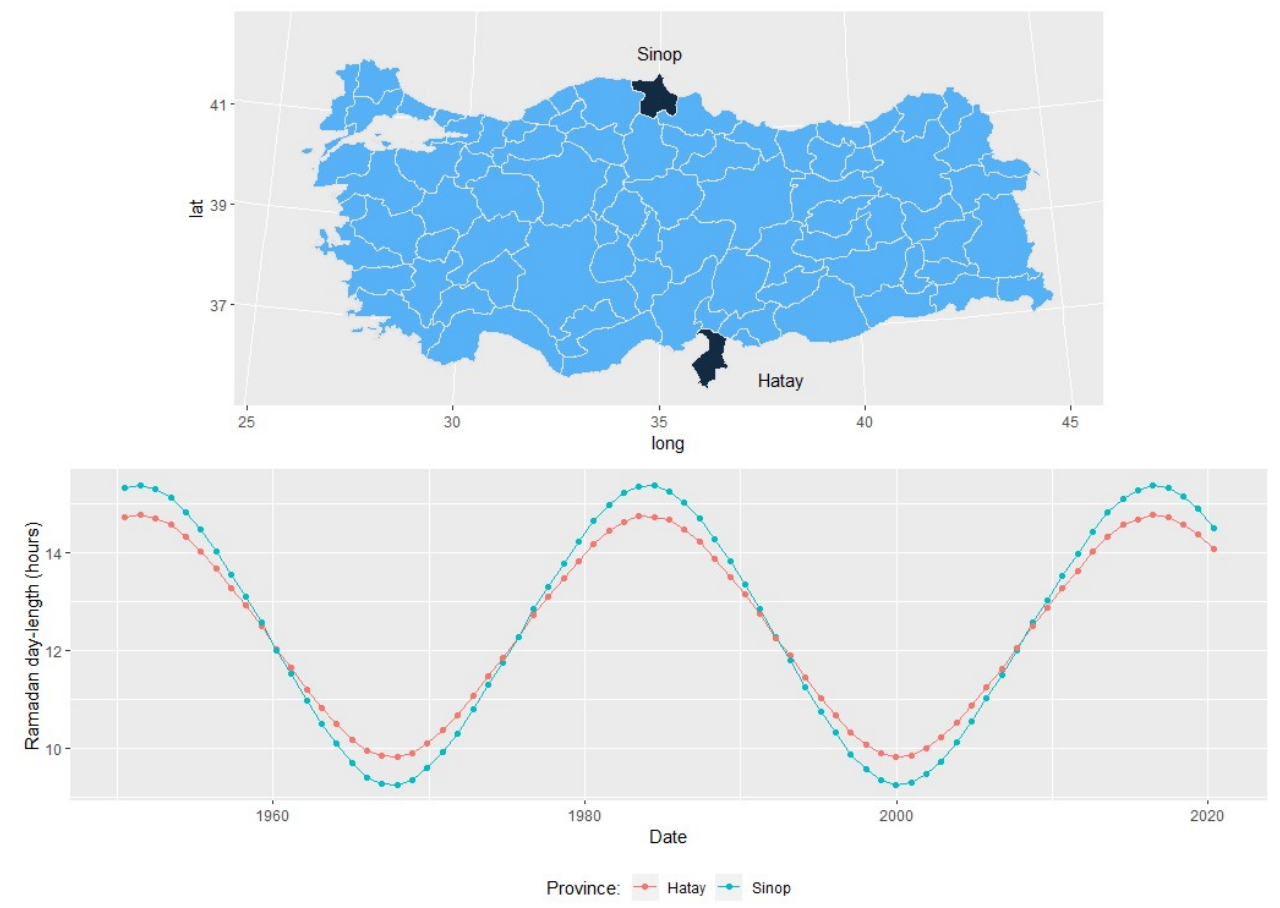

\section{Data and Results}

We collected detailed historical data on the provincial vote shares of all political parties in parliamentary elections and matched those with the length of the median Ramadan day in the year that precedes the election. The key outcome variable, vote shares of Islamist parties is measured in the 12 general elections that were held between 1973 and 2018. To conduct robustness checks and tests of theoretical mechanisms and we also collected data on GDP growth, number of Mosques per 1000, number of Quran course attendants per 1000, number of religious personnel per 1000, prevalence of non-orthodox Muslims (i.e. Alevis). Finally, we analyze the 2008 and 2013 Demographic and Health Survey which include data on individuallevel religious practices (fasting, praying, and veiling).

Figure 2 shows the vote shares of Islamist political parties since 1973 per province with the median Ramadan day length. Table 1 below shows the effect of the median Ramadan day length 
on the vote share of Islamist political parties, some placebo outcomes (turnout, population), and on the vote share of center-left parties. These models include election year and province fixedeffects, which absorb the effects of all variables that are constant over time in a province and any year-on-year shifts in political preferences that is constant across provinces. The causal identification of the effect of Ramadan day length rests on the idiosyncratic variation of day length due to the interaction between latitude and seasonal cycles of Ramadan.

The results show that Ramadan day length does not have significant effects on electoral turnout, the vote shares of center-left parties, and, as a placebo test, on population. It has however a large effect on the vote for Islamic parties: an hour increase in fasting hours in Ramadan in the year before the general election increases the vote share of Islamic parties by about 7 percentage points. To appreciate how large an effect this is consider that it corresponds to a $23 \%$ increase relative to the overall mean vote share of Islamic parties, which is $31 \%$. The effect is robust to controlling for population, GDP growth, turnout, and number of parliamentary seats. ${ }^{3}$

Figure 2. Vote shares of ISLAMIST PARTIES AND AVERAge DAY LENGTH. EACH POINT IS A PROVINCE. The GAP BETWEEN 1980 AND 1985 CORRESPONDS TO THE POST-MILITARY COUP PERIOD WHEN ISLAMIST PARTIES WERE BANNED.

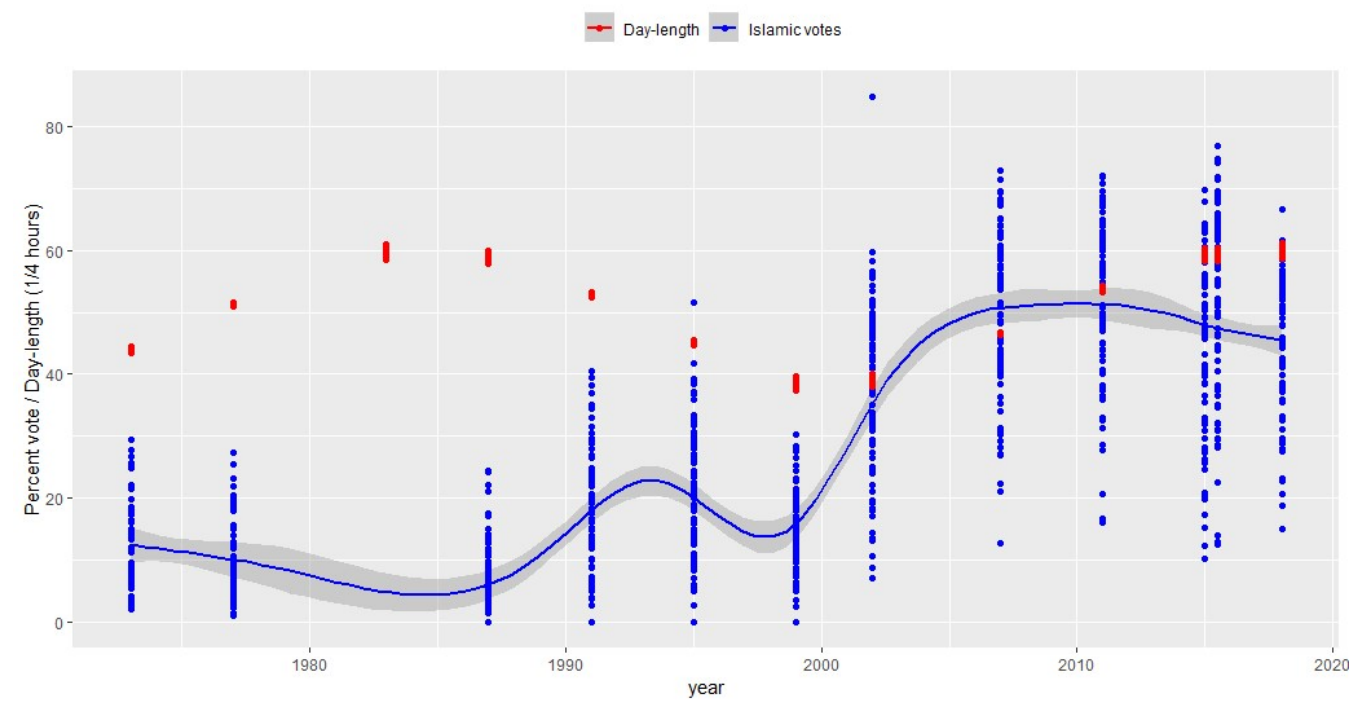

${ }^{3}$ As an aside, we find that an hour increase in Ramadan day reduces economic growth by about 1.32 percentagepoints, replicating Campante and Yanagizawa-Drott (2013), though this effect is statistically insignificant $(P=.167)$. 
TABLE 1. EFFECT OF FASTING HOURS (DAY LENGTH) DURING RAMADAN ON VARIOUS OUTCOME VARIABLES BASED ON REGRESSION MODELS THAT INCLUDE FIXED-EFFECTS FOR PROVINCES AND ELECTION YEARS.

\begin{tabular}{llllll}
\hline Variable & $\begin{array}{l}\text { Islamic } \\
\text { Votes }\end{array}$ & $\begin{array}{l}\text { Islamic } \\
\text { Votes }\end{array}$ & Turnout & Population & $\begin{array}{l}\text { Left } \\
\text { votes }\end{array}$ \\
\hline Ramadan hours & $\begin{array}{l}\mathbf{6 . 5 2} * * * \\
\mathbf{( 2 . 1 8 )}\end{array}$ & $\begin{array}{l}\mathbf{7 . 4 2 * * *} \\
\mathbf{( 2 . 3 8 )}\end{array}$ & $\begin{array}{l}-.82 \\
(.97)\end{array}$ & $\begin{array}{l}-5848 \\
(161743)\end{array}$ & $\begin{array}{l}.52 \\
(2.11)\end{array}$ \\
Covariates & No & Yes & No & No & No \\
$\begin{array}{l}\text { Election year } \\
\text { fixed-effects }\end{array}$ & Yes & Yes & Yes & Yes & Yes \\
$\begin{array}{l}\text { Province fixed- } \\
\text { effects }\end{array}$ & Yes & Yes & Yes & Yes & Yes \\
N (provinces) & 81 & 81 & 81 & 81 & 81 \\
N (observations) & 944 & 944 & 1343 & 4615 & 1360 \\
\hline
\end{tabular}

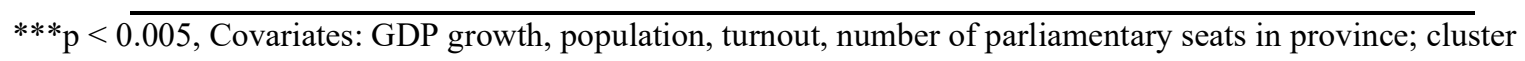
robust standard errors in parentheses. Number of observations vary per model because of historical features of data (e.g. first Islamist political party participated in elections in 1973 whereas left-wing CHP since 1950; population is measured every year while elections happen every five years). Results are robust to restricting analyses to the same set of observations.

\section{Robustness checks}

If our main finding in Table 1 is genuine rather than a statistical artefact or a fluke, we should observe the effect of longer fasting length on Islamic votes to be heterogeneous: the more religious a province is, the stronger will be the effect. Table 2 reports tests of effect heterogeneity which support our expectations. Firstly, the more Alevis live in the region, the lower is the effect of the Ramadan day length on Islamic votes. Alevis are unorthodox Muslims who do not fast during Ramadan (World Directory of Minorities and Indigenous Peoples 2018) and who are traditionally distant from political Islam (Tahire and Göker 2000). Next, the more Mosques and religious personnel there are in a province, the stronger is the effect of Ramadan day length on Islamic votes. Figure 3 demonstrates this interaction between religiosity of a province (constructed as a composite measure from the prevalence of Alevis, religious personnel, and Mosques) and Ramadan day length. These findings make us more confident that the effect of Ramadan day length on Islamic votes that we find is genuine. 
TAble 2. Heterogeneous effects of fasting hours length during RAMAdan on IsLamic votes.

\begin{tabular}{|c|c|c|c|c|c|}
\hline Variable & $\begin{array}{l}\text { Islamic } \\
\text { Votes }\end{array}$ & $\begin{array}{l}\text { Islamic } \\
\text { Votes }\end{array}$ & $\begin{array}{l}\text { Islamic } \\
\text { Votes }\end{array}$ & $\begin{array}{l}\text { Islamic } \\
\text { Votes }\end{array}$ & $\begin{array}{l}\text { Islamic } \\
\text { Votes }\end{array}$ \\
\hline Ramadan hours & $\begin{array}{l}6.52 * * * \\
(2.18)\end{array}$ & $\begin{array}{l}3.79 \\
(2.45)\end{array}$ & $\begin{array}{l}5.10 * \\
(2.30)\end{array}$ & $\begin{array}{r}2.29 \\
(2.43)\end{array}$ & $\begin{array}{l}3.19 \\
(2.66)\end{array}$ \\
\hline $\begin{array}{l}\text { Ramadan hours } \times \\
\text { Quran course pc }\end{array}$ & & $\begin{array}{l}.17 * \\
(.08)\end{array}$ & & & \\
\hline $\begin{array}{l}\text { Ramadan hours } \times \\
\% \text { Alevi }\end{array}$ & & & $\begin{array}{l}-.05+ \\
(.03)\end{array}$ & & \\
\hline $\begin{array}{l}\text { Ramadan hours } \times \\
\text { Mosques pc }\end{array}$ & & & & $\begin{array}{l}.40 * * * \\
(.11)\end{array}$ & \\
\hline $\begin{array}{l}\text { Ramadan hours } \times \\
\text { Religious personnel } \\
p c\end{array}$ & & & & & $\begin{array}{l}.12 * \\
(.04)\end{array}$ \\
\hline Year FE & Yes & Yes & Yes & Yes & Yes \\
\hline Province FE & Yes & Yes & Yes & Yes & Yes \\
\hline $\mathrm{N}$ & 944 & 944 & 944 & 944 & 944 \\
\hline
\end{tabular}

*** $P<0.005, * P<0.05,+P<0.1$; Cluster robust standard errors in parentheses.

Scholars argue that controlling for the lagged dependent variable may account for path dependency or autocorrelation of residuals in panel regressions, though it may also bias downwards the coefficients for other explanatory variables (Keele and Kelly 2006). In our case, adding one-election lagged values of Islamic votes as a predictor of Islamic votes in the current election does not change substantially the effect of Ramadan day length on Islamic votes (coefficient for Ramadan day length $=5.04$, S.E. $=1.9, P=0.010$ ). Likewise, controlling for leftwing votes does not affect our results substantially (coefficient for Ramadan day length $=5.12$, S.E. $=2.15, P=0.020$ ). Figure 5 shows that the association between Ramadan day length and Islamic votes is monotonic and there is no leveling off or reversal of the effect. Finally, we assessed the robustness of the effect of Ramadan day length on Islamic votes to dropping cases. We dropped one-by-one each of the 81 provinces with all the elections that took place in that province and estimated the effect. Likewise, we dropped one-by-one each of the 12 elections and estimated the effect. Figure 4 shows that our findings are not driven by a single province or any one election. 
FIGURE 3. INTERACTION EFFECT OF RELIGIOSITY OF A PROVINCE AND RAMADAN DAY LENGTH ON ISLAMIC VOTES. RELIGIOSITY OF A PROVINCE IS A COMPOSITE SCORE CONSTRUCTED FROM THE PREVALENCE OF Alevis, Religious personnel, and Mosques in a PRovince. Predicted ISLAMIC Vote SHARE IS OBTAINED FROM A REGRESSION MODEL WITH FIXED-EFFECTS OF PROVINCES AND ELECTION YEARS.

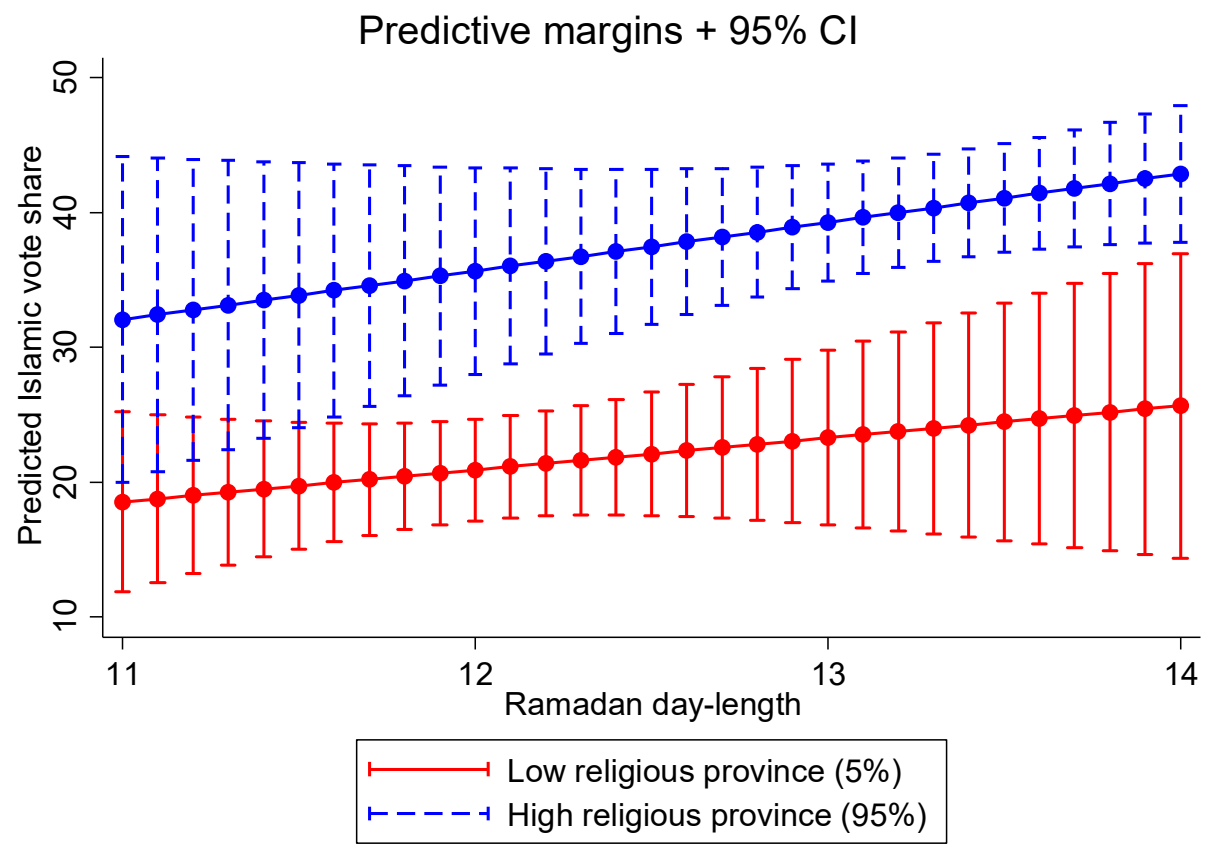

Figure 4. ROBustness of the EFFECT Of RAMADAN DAY LENGTH ON ISLAMIC VOTES TO DROPPING PROVINCES AND ELECTIONS. DASHED LINE IS THE EFFECT OBTAINED WITH THE FULL SAMPLE.

A Dropping provinces one by one

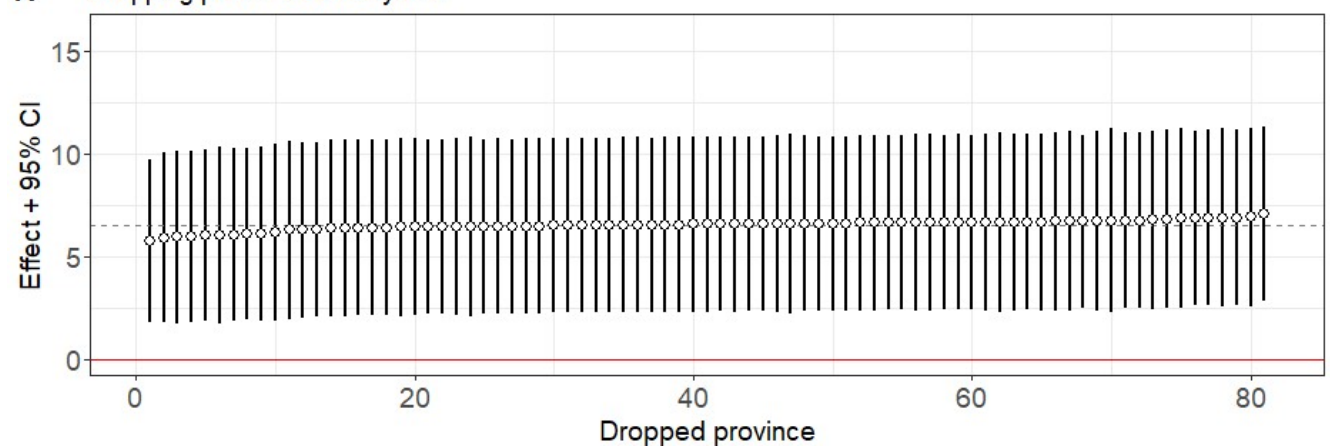

B Dropping elections one by one

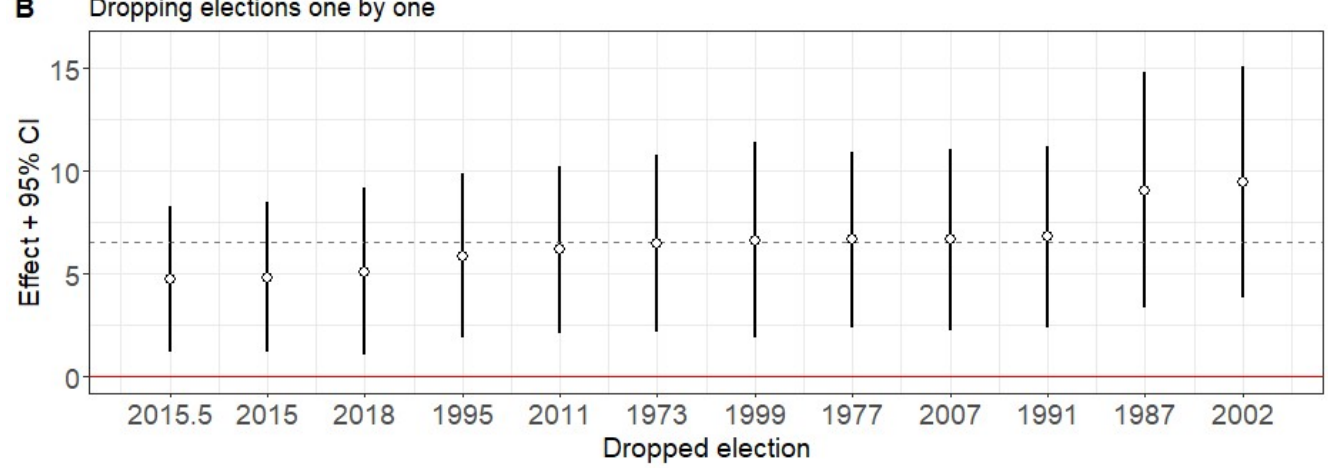




\section{Mechanisms: screening or commitment}

The two classes of mechanisms, which might be triggered by lengthier fasting and which we discussed above, namely screening and commitment both predict a positive effect of Ramadan day length on Islamic votes. We can, however, disentangle the mechanisms indirectly by looking at religious participation. The screening mechanism predicts a negative effect of Ramadan day length on the prevalence of religious participation: those who are not prepared to bear the costs of longer fasting screen themselves out of the religious community and reduce their religious participation. The commitment mechanism, however, does not result in a reduction in religious participation. In fact, longer fasting can increase the prevalence of religious participation. Shared painful experiences, often a component of religious rituals, are shown to increase group identity (Bastian, Jetten and Ferris 2014). The pain makes the experience highly memorable. In addition, when painful experiences are shared, they also increase the salience of others who take part. This, in turn, as argued by Bastian et al. (2014), increases group identity, solidarity, and cohesion. This increase in group identity and solidarity is expected to increase religious participation even among the less religious through conformity and social pressure (Kuran 1995).

In the models in Table 3 we test whether Ramadan day length affects religious participation measured as the number of voluntary Quran course participants and mosques in a province; and the individual probability of veiling, praying regularly, and fasting. We find that Ramadan day length has positive effects on all variables, and the effect on fasting is statistically significant. Moreover, the interaction term in Model 3 in Table 3 shows that even for people who do not pray regularly, the effect of Ramadan day length on praying is positive and significant $(b=0.14, P=$ $0.019)$. For those who pray regularly, Ramadan day length has a stronger effect $(b=0.14+0.013$ $=0.15, P=0.008)$. Hence, significantly more people fast when Ramadan days are longer. Other forms of religious participation increase as well in Ramadans with longer days, albeit in a statistically insignificant way. These results support the commitment mechanism as opposed to screening.

The timing of elections may help us to disentangle commitment from screening too. ${ }^{4}$ The screening process would result in a change in the composition of religious organizations: when fasting becomes costlier individuals who are less religiously engaged will stay away from religious organizations and communities. This will result in a long-term effect of Ramadan day length due to structural changes in Islamist organizations. The commitment mechanism, by contrast, relies on psychological states, such as cognitive dissonance, self-perception, and increased group identity due to collective hardship experiences. These psychological states are expected to diminish over time once Ramadan is over and the memories of long fasting wane (Fridhandler 1986). Hence, one can predict from the commitment mechanisms that if an election takes place many months after Ramadan, the effect of Ramadan day length on Islamist votes should weaken.

We test this prediction by adding an interaction between Ramadan day length and a variable that records the time elapsed (in months) between the last day of the most recent Ramadan and the

\footnotetext{
${ }^{4}$ We thank Richard Sosis for suggesting that timing of elections can be used to disentangle screening from commitment.
} 
day in which the election took place in the first model in Table 1. The interaction coefficient shows that for each month distance between Ramadan and elections, the effect of Ramadan day length on the vote shares of Islamist parties decreases by .73 $(P=0.094)$. Figure 5 demonstrates this interaction by displaying the association between Ramadan day length and Islamist votes in elections that took place either within six months after the preceding Ramadan (left panel) or beyond six months (right panel). In both panels, there is a positive association, but the slope is steeper in the latter. This finding, again, weakly supports the commitment mechanism as opposed to screening.

TABLE 3. RAMAdAN DAY LENGth AND Religious PARTiCipation.

\begin{tabular}{|c|c|c|c|c|c|c|}
\hline Variable & $\begin{array}{l}\text { M1: } \\
\text { Quran } \\
\text { course pc }\end{array}$ & $\begin{array}{l}\text { M2: } \\
\text { Mosques } \\
\text { pc }\end{array}$ & $\begin{array}{l}\text { M3: } \\
\text { Pr(fast) }\end{array}$ & $\begin{array}{l}\text { M4: } \\
\text { Pr(fast) }\end{array}$ & $\begin{array}{l}\text { M5: } \\
\text { Pr(veil) }\end{array}$ & $\begin{array}{l}\text { M6: } \\
\text { Pr(pray) }\end{array}$ \\
\hline Ramadan hours & $\begin{array}{l}1.44 \\
(.92)\end{array}$ & $\begin{array}{l}.12 \\
(.09)\end{array}$ & $\begin{array}{l}.16^{*} \\
(.07)\end{array}$ & $\begin{array}{l}.14^{*} \\
(.06)\end{array}$ & $\begin{array}{l}.07 \\
(.09)\end{array}$ & $\begin{array}{l}.10 \\
(.10)\end{array}$ \\
\hline $\begin{array}{l}\text { Ramadan hours } \\
\times \text { praying }\end{array}$ & & & & $\begin{array}{l}.013^{*} \\
(.006)\end{array}$ & & \\
\hline Covariates & No & No & Yes & Yes & Yes & Yes \\
\hline Year FE & Yes & Yes & Yes & Yes & Yes & Yes \\
\hline Province FE & Yes & Yes & Yes & Yes & Yes & Yes \\
\hline $\mathrm{N}$ & 4187 & 2679 & 14326 & 14326 & 14323 & 14326 \\
\hline
\end{tabular}

*P<0.05; cluster robust standard errors in parentheses. M3, M4, M5, M6 are fitted using individual-level data from the 2008 and 2013 Demographic and Health Survey with adjusting for age, marital status, ethnicity, income, urbanicity, education, household wealth, number of children - without these covariates the estimates effects are virtually the same. All estimates are obtained from linear regressions with fixed-effects for provinces and years. 
Figure 5. BinNed SCATTER PLOT OF THE ASSOCIATION BETWEen ISLAMIC VOTE SHARES AND RAMAdAN DAY-LENGTH BROKEN DOWN BY DISTANCE BETWEEN THE MOST RECENT RAMADAN AND THE ELECTION DAY. EACH POINT IS THE AVERAGE OF SEVERAL PROXIMATE DATAPOINTS.
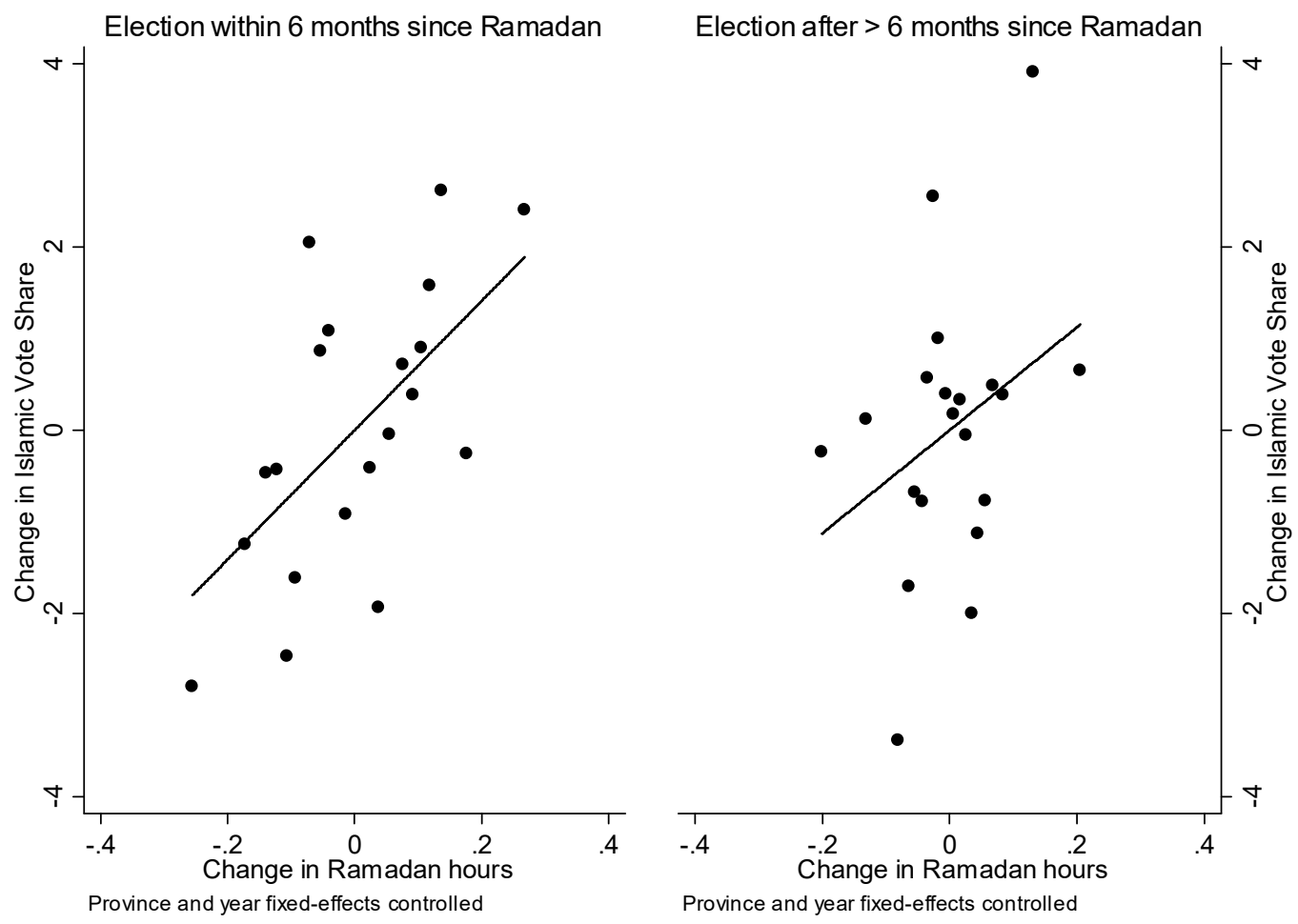

\section{Conclusions}

In the science of religion costly religious practices are thought to be an important factor in the diffusion and resilience of religious organizations and communities (Iannaccone 1992, Iannaccone 1995, Sosis and Alcorta 2003, Sosis and Bulbulia 2011). Such practices are thought to enhance religious communities through two mechanisms: screening that helps organizations screen out mimics and free-riders, and commitment through which higher effort results in higher religious engagement. The available evidence for this argument has been associational. In this study we present strong causal evidence.

Our study also offers a theoretical contribution. Using various data sources, we could disentangle the screening mechanism from commitment, and test both. The results support the latter. We show that costly religious practices can increase commitment to religious causes, even without a mechanism that screens out the less engaged free riders and mimics. Overall, our results strengthen a key conjecture of the science of religion and help understand the success and resilience of religions.

Our study also contributes to a wider debate among scientists on the evolutionary study of religions (Boyer 2001, Bulbulia 2004, Norezanyan and Shariff 2008, Norezanyan 2013, Purzycki et al. 2018, Lang et al. 2019). One of the evolutionary approaches to the study of human 
behavior is behavioral ecology (Sosis and Bulbulia 2011). Behavioral ecologists examine whether particular behaviors are adaptively attuned to environmental conditions by measuring the costs and benefits of the behavior. In so doing they document selective pressures which may have acted upon human decision mechanisms. The contribution of behavioral ecology to science of religion, however, has been rather limited compared to other evolutionary approaches such as evolutionary psychology and dual inheritance theory (Sosis and Bulbulia 2011). One of the reasons for this limitation is that it is inherently difficult to clearly define and measure the costs and benefits of religious beliefs and practices. Our study can be regarded as an example of a behavioral ecological approach to religion. Using Ramadan fasting as a natural experiment we present a clearly defined and exogenously manipulated cost of religious practice. We show that religious fasting can be adaptive due to its commitment functions. It is adaptive because the duration of fasting affects the political power Islamist parties entertain. Islamic governance is shown to increase social welfare and assistance practicing Muslims receive, and hence increase marriage and fertility among Muslims (Aksoy and Billari 2018).

On an end note, in the Northern hemisphere we are now in an era during which Ramadan day length peaks. In the upcoming years Ramadan day length will shorten. We thus expect that the Islamic parties will face a steeper uphill struggle to repeat their electoral success of recent years, particularly at northern latitudes where the decline in Ramadan day length will be stronger.

\section{Material and methods}

Electoral data and province GDPs were obtained from Turkish Statistical Institute (TurkStat).

Province GDPs were available since 1988 and GDP for year 2002 was not reported by TurkStat, hence it was interpolated by averaging the 2001 and 2003 values. A yearly growth rate was calculated from annual nominal GDPs. Median Ramadan day length was calculated based on data published by Bogazici University Kandilli Observatory on sunrise and sunset hours per province. Proportion of Alevis was based on the 2007 Konda survey (KONDA 2007) calculated at the Nuts-1 level. The number of religious personnel per 1000 capita was obtained Turkish Presidency of Religious Affairs (TPRA) and was based on values reported for 2016. We use two measures of the number of Mosques per 1000. One is based on static values reported for 2016 by TPRA, the other is a dynamic measure reported by TurkStat annually since 1981 (with gaps). Annual provincial populations were available from TurkStat since 1927 (with gaps). The number of voluntary Quran course attendants per 1000 was reported by TurkStat annually since 1961 (with gaps). ${ }^{5}$ Time since last Ramadan was calculated by counting the number of months since the last day of the most recent Ramadan until the election date. Individual-level data on fasting, praying, and veiling was obtained from the 2008 and 2013 Demographic and Health Surveys (DHS). DHS includes representative samples of (ever-married) women. Fasting, praying, and veiling were measured in a binary way (whether a woman fasts, prays, and veils regularly).

The main dependent variable, Islamic vote share reflects the vote shares of MSP in 1973 and 1977, RP in 1986 to 1996, FP in 1999, and the sum of AKP and Saadet after 1999. MSP is the first explicitly Islamist political party that participated in the elections in 1973. MSP was

\footnotetext{
${ }^{5}$ We downloaded the dynamic data on the number of Mosques, Quran course participants, and provincial populations from (Livny, Forthcoming) who obtained them from TurkStat and cleaned.
} 
disbanded after the 1980 military coup. In 1983, the MSP reorganized as the Welfare Party (RP), which was then replaced in 1998 by the Virtue Party (FP). The FP was almost immediately closed by the constitutional court in 2001, an act that split Turkey's political Islam into two: The Felicity Party (Saadet Partisi) and the AK Parti (AKP), led by Recep Tayyip Erdogan.

The center-left vote share is calculated from the vote shares of CHP, DSP, SHP, and HP. If more than one of those parties took place in an election, the center-left vote share is calculated as the sum of the vote shares of those parties.

The religiosity index of a province used in Figure 3 was created as a composite score constructed from the number of Alevis, religious personnel, and the static measure of the number of mosques in a province (Chronbach's $\alpha=.59$ ).

TurkStat publishes annual statistics on population, GDP growth, Quran course participants, and the dynamic measure of the number of Mosques per 1000 with gaps. We used multiple imputation with chained equations and predictive mean matching to impute missings in those variables (Van Buuren 2007). Listwise deletion of those missing cases results in virtually the same results.

Data and replication material are available at [link to be inserted, full replication material is submitted with the manuscript].

References

Akkoyunlu, K. (2017) Electoral integrity in Turkey: from tutelary democracy to competitive authoritarianism in Başer, B. and Öztürk, A.E (eds), Authoritarian Politics in Turkey: Elections, Resistance and the AKP, London: I.B. Tauris

Aksoy, O. and Billari, F.C. (2018) Political Islam, marriage, and fertility: evidence from a natural experiment, American Journal of Sociology 123 (5), 1296-1340.

Aksoy, O. and Gambetta, D. (2019) The politics behind the veil. SocArxiv url: https://osf.io/preprints/socarxiv/ezpaq/download.

Aksoy, O. and Gambetta, D. (2016) Behind the veil: The strategic use of religious garb, European Sociological Review 32(6): 792-806.

Almond, D. \& Mazumder, B. A. (2011) Health capital and the prenatal environment: the effect of Ramadan observance during pregnancy, American Economic Journal: Applied Economics 3(4): 56-85.

Bastian, B., Jetten, J. and Ferris, L. (2014) Pain as Social Glue: Shared Pain Increases Cooperation, Psychological Science.

Bem, D. (1965) An experimental analysis of self-persuasion. Journal of Experimental Social Psychology 1:199-218.

Berman, E., 2011. Radical, religious, and violent: The new economics of terrorism. MIT press.

Boyer, P (2001) Religion Explained: The Evolutionary Origins of Religious Thought.

Bulbulia, J. (2004) Religious costs as adaptations that signal altruistic intention, Evolution and Cognition 10: 19-38. 
Campante, F., \& Yanagizawa-Drott, D. (2015) Does religion affect economic growth and happiness? Evidence from Ramadan, Quarterly Journal of Economics 130(2): 615-658.

Carvalho, J.P., 2013. Veiling. Quarterly Journal of Economics, 128(1): 337-370.

Durkheim, E. ([1912], 1995) The Elementary Forms of Religious Life, Free Press.

Festinger, L. (1957) A Theory of Cognitive Dissonance. Stanford: Stanford University Press.

Fridhandler, B.M. (1986) Conceptual note on state, trait, and the state-trait distinction. Journal of Personality and Social Psychology, 50(1), p.169.

Hall, D. L., Cohen, A. B., Meyer, K. K., Varley, A. H. \& Brewer, G. A. (2015) Costly signaling increases trust, even across religious affiliations, Psychological Science 26(9): 1368-1376.

Hodler, R., Raschky, P. \& Strittmatter, A. (2019) Religiosity and terrorism: evidence from Ramadan fasting, CEPR Discussion Paper No. DP13257, URL (accessed on 28.08.2019): https://papers.ssrn.com/sol3/papers.cfm?abstract_id=3270935.

Hornung, E., Schwerdt, G., Strazzeri, M. (2018) Religious practice and student performance: Evidence from Ramadan fasting, Working Paper url (accessed on 28.08.2019): https://www.cesifo-

group.de/dms/ifodoc/docs/Akad_Conf/CFP_CONF/CFP_CONF_2018/ee18-

Hanushek/Papers/ee18_Schwerdt.pdf

Iannaccone, L. (1992) Sacrifice and stigma, Journal of Political Economy 100(2): 271-291.

Iannaccone, L. (1994) Why strict churches are strong, American Journal of Sociology 99, 11801211.

Irons, W. (2001) Religion as a Hard-to-Fake Sign of Commitment. In Evolution and the Capacity for Commitment, R. Nesse, ed. Pp. 292-309. New York: Russell Sage.

Keele, L., \& Kelly, N. J. (2006) Dynamic models for dynamic theories: The ins and outs of lagged dependent variables. Political Analysis, 14(2), 186-205.

KONDA Research and Consultancy. 2007. Religion, secularism and the veil in daily life. Available at http://www.konda.com.tr/html/dosyalar/ghdl\&t_en.pdf.

Kuran, Timur. (1995) Private truths, public lies: The social consequences of preference falsification. Cambridge, MA: Harvard University Press.

Lang, M., Purzycki, B. G., Apicella, C. L., Atkinson, Q. D., Bolyanatz, A., Cohen, E., ... \& McNamara, R. A. (2019) Moralizing gods, impartiality and religious parochialism across 15 societies. Proceedings of the Royal Society B, 286(1898), 20190202.

Livny, A. (Forthcoming) Trust and the Islamic advantage: religious-based movements in Turkey and the Muslim world, Cambridge University Press.

McBride, M. (2007) Club Mormon: free-riders, monitoring, and exclusion in the LDS Church, Rationality and Society 19(4): 395-424.

Norenzayan, A. (2013) Big Gods: How Religion Transformed Cooperation and Conflict, Princeton University Press. 
Norenzayan A. \& Shariff A. (2008) The origin and evolution of religious prosociality, Science 322:58-62.

Oosterbeek, H., \& van der Klaauw, B. (2013) Ramadan, fasting and educational outcomes, Economics of Education Review, 34, 219-226.

PEW (2013) The World's Muslims: religion, politics and society. PEW survey dataset and report, URL: https://www.pewforum.org/dataset/the-worlds-muslims/ (accessed on 30/09/2019).

Power, E.A. (2017) Social support networks and religiosity in rural South India, Nature Human Behaviour, 1:0057.

Purzycki, B. G. et al. (2016) Moralistic gods, supernatural punishment and the expansion of human sociality. Nature 530, 327-330.

Purzycki, B. G., Henrich, J., Apicella, C., Atkinson, Q. D., Baimel, A., Cohen, E., ... \& Norenzayan, A. (2018) The evolution of religion and morality: a synthesis of ethnographic and experimental evidence from eight societies. Religion, Brain \& Behavior, 8(2), 101-132.

Sosis, R., 2003. Why aren't we all Hutterites? Costly signaling theory and religious behavior Human Nature, 14(2): 91-127.

Sosis, R., \& Alcorta, C. (2003) Signaling, solidarity, and the sacred: The evolution of religious behavior. Evolutionary Anthropology: Issues, News, and Reviews: Issues, News, and Reviews, 12(6), 264-274.

Sosis, R., \& Bulbulia, J. (2011). The behavioral ecology of religion: The benefits and costs of one evolutionary approach. Religion, 41(3), 341-362.

Tahire, E. and Göker. E. (2000) Alevi Politics in Contemporary Turkey. Middle Eastern Studies, 36(4):99-118.

Tan, J. \& Vogel, C. (2008) Religion and trust: an experimental study, Journal of Economic Psychology 29(6): 832-848.

van Buuren, S. (2007) Multiple imputation of discrete and continuous data by fully conditional specification. Statistical Methods in Medical Research 16: 219-242.

World Directory of Minorities and Indigenous Peoples (2018) Alevis, online report (accessed on 11.10.2019), url: https://minorityrights.org/minorities/alevis/ 